\title{
Mapping of water-related ecosystem services in the uMngeni catchment using a daily time-step hydrological model for prioritisation of ecological infrastructure investment - Part 1: Context and modelling approach
}

\author{
CJ Hughes ${ }^{1 *}$, G de Winnaar ${ }^{2}$, RE Schulze', M Mander ${ }^{3}$ and GPW Jewitt ${ }^{1,4}$ \\ ${ }^{1}$ Centre for Water Resources Research, University of KwaZulu-Natal, Rabie Saunders Building, Carbis Road, Pietermaritzburg, South Africa \\ ${ }^{2}$ GroundTruth Water, Wetlands and Environmental Engineering, 9 Quarry Road, Hilton, South Africa \\ ${ }^{3}$ FutureWorks, The Southern Right, Brenton on Sea, Knysna, South Africa \\ ${ }^{4}$ Umgeni Water Chair of Water Resources Management, University of KwaZulu-Natal, South Africa
}

\begin{abstract}
South Africa is a semi-arid country which frequently faces water shortages, and experienced a severe drought in the 2016 and 2017 rainfall seasons. Government is under pressure to continue to deliver clean water to the growing population at a high assurance of supply. Studies now show that the delivery of water may be sustained not only through built infrastructure such as dams and pipelines, but also through investment in ecological infrastructure (EI). A daily time-step hydrological model was used to map areas which should be prioritised for protection or rehabilitation to sustain the delivery of water-related ecosystem services within the uMngeni catchment. We focused on three water-related ecosystem services, i.e.: water supply, sustained baseflow, erosion control/avoidance of excessive sediment losses. The two key types of degradation were modelled, namely, overgrazing and the invasion of upland areas by Black Wattle (Acacia mearnsii). This, Part 1 of a paper in 2 parts, provides a discussion on the role of EI in delivering water-related ecosystem services, describes the motivation for the study, and the methods used in modelling and mapping the catchment. The results of this modelling exercise are presented in Part 2, which also explores and illustrates the potential hydrological benefits of rehabilitation and protection of EI in the uMngeni Catchment.
\end{abstract}

Keywords: water, ecosystem services, hydrological modelling, ecological infrastructure, water security

\section{INTRODUCTION}

South Africa, as a semi-arid country, frequently faces water shortages and in the 2016 and 2017 rainfall seasons experienced a severe drought. Government is under pressure to continue to deliver clean water to the growing population at a high assurance of supply. Several studies have suggested that the delivery of water may be sustained not only through built infrastructure such as dams and pipelines, but also through investment in ecological infrastructure.

Ecological infrastructure (EI) is defined as 'naturally functioning ecosystems that produce and deliver valuable services to people'. This term is similar to the widely used 'natural capital', which is defined as 'the world's stocks of natural assets which include geology, soil, air, water and all living things (Natural Capital Forum, 2017)' (Jewitt et al., 2015a p. 1). Delivery of water-related ecosystem services is highly dependent on healthy EI (Brauman et al., 2007), which plays a key role in determining the catchment's capacity to firstly receive precipitation, and in turn the distribution of water through varying soil/water responses. The condition of the catchment (e.g. pristine vs overgrazed) therefore determines the partitioning of rainfall above and below the earth's surface, as well as the distribution of water within a catchment. Healthy vegetation cover protects, and its root system binds, the topsoil,

To whom all correspondence should be addressed.

푱 +27 797077787 ;

e-mail: catherinejhughes@outlook.com

Received 26 May 2016; accepted in revised form 20 September 2018. reducing its exposure and mobilisation by wind, rainfall and surface runoff.

The role of EI in delivering water-related ecosystem services is well recognised (Brauman et al., 2007; Guswa et al., 2014; Elmqvist et al., 2015). These services include, amongst others, flood attenuation, water purification through biophysical and biological processes, i.e., retention of sediments and nutrients, pollution dilution, sustaining baseflows during dry periods and provision of water supply of high quality (Elmqvist et al., 2007; Guswa et al., 2014), see Fig. 1).

Degradation of EI through various human-induced processes such as overgrazing, inappropriate burning regimes, poor agricultural practices (livestock and cropping) and the proliferation of invasive alien plants (IAPs, see definitions of 'invasive' and 'alien' in Richardson et al., 2000) reduces its capability to deliver water-related ecosystem services of the highest quality. In this study, we have concentrated on the outputs from the modelling of two key anthropogenic drivers of degradation, namely, overgrazing and the proliferation of IAPs.

Degradation can have a marked effect on catchment hydrology (Fig. 2), such as reducing streamflows (water supply), causing high-energy runoff which mobilises excessive amounts of sediments, and reducing infiltration of precipitation to the lower layers of soil with associated lower volumes of baseflow and groundwater recharge. These effects lead to negative impacts on water-related ecosystem services, such as reducing flood attenuation capacity, water supply and water quality. Additionally, all of these can affect human communities in terms of health, agricultural productivity and safety. This is particularly important in rural and peri-urban areas where 


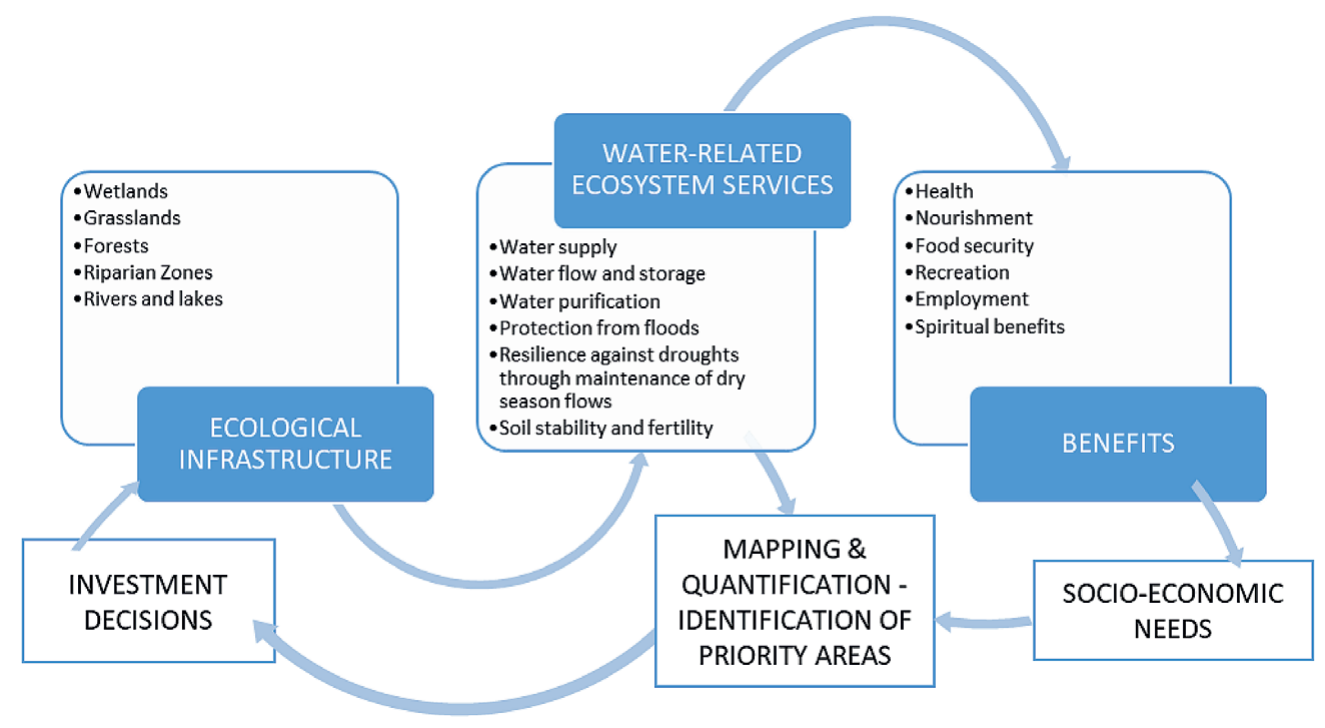

Figure 1

Water-related ecosystem services and benefits provided by ecological infrastructure

people are immediately dependent on run-of-river water supply and quality. The effective rehabilitation of degraded areas, when taking into account the need for considering the entire ecosystem and the reinstatement of ecological processes, can improve the delivery of water-related ecosystem services.

Perhaps the most important aspect of water distribution is the partitioning of water into surface and sub-surface water, the latter often being derived from infiltration and percolation through the soil profile, as a result of which rainfall becomes shallow or deep groundwater which contributes to sustained baseflows and thus water supply (Kosgei et al., 2007; Wenninger et al., 2008; Van Tol et al., 2010). Dilution of pollutants through a sufficient and sustained water supply has a direct bearing on water quality. This, in turn, has a marked effect on a number of ecosystem service benefits to society, including human health (Keeler et al., 2012). Identification of socio-economic needs such as human health (and hence desired benefits derived from ecosystem services) can drive the mapping of ecosystem services and in turn the identification of priority areas for investment into ecological infrastructure protection and/or rehabilitation. Such investments could include the securing and rehabilitation of naturally functioning ecosystems, including grasslands, riparian zones and wetlands.

In naturally perennial systems, baseflow is maintained by healthy ecological infrastructure through providing steady infiltration and percolation. Baseflow drives the functionality of many water-related ecosystem services (see Fig. 3), notably water quality and run-of-river abstraction in the dry season (both of which are key considerations in times of drought) and for aquatic ecosystem function throughout the year to support the ecological reserve, and ensure that primary water users have sustained access to sufficient, good quality water.

In contrast to baseflow, surface or near-surface runoff (referred to as quickflow), i.e., the water which runs off the surface or near-surface following a rainfall event, does not infiltrate to the lower layers of soil (Le Maitre et al., 2014). While it contributes to the water supply of the river, should the natural balance between quickflow and baseflow be disrupted, too much quickflow can mobilise excessive sediments and nutrients from the surface (Dlamini et al., 2014). Sediments and

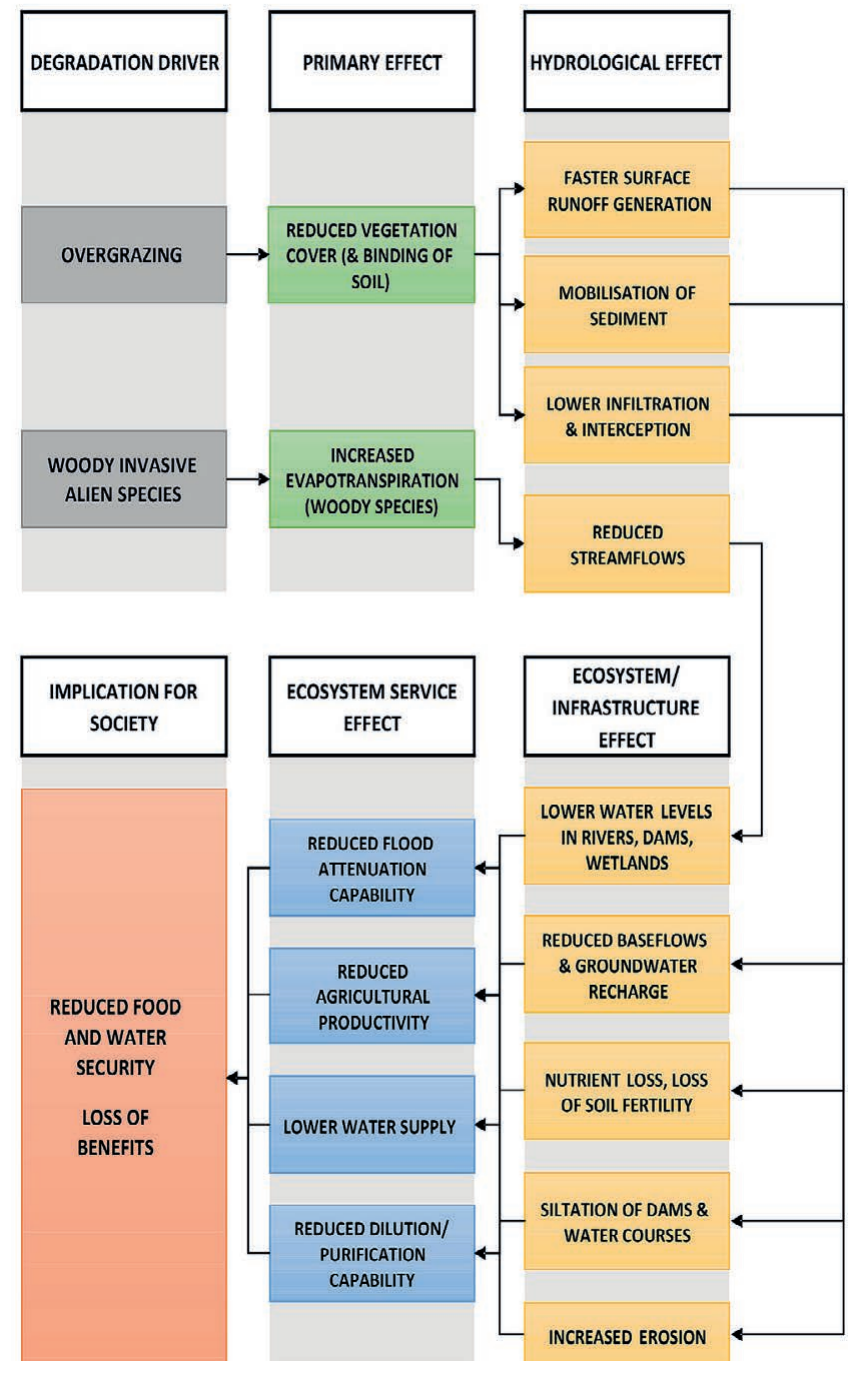

Figure 2

Degradation effects of overgrazing and woody IAPs 


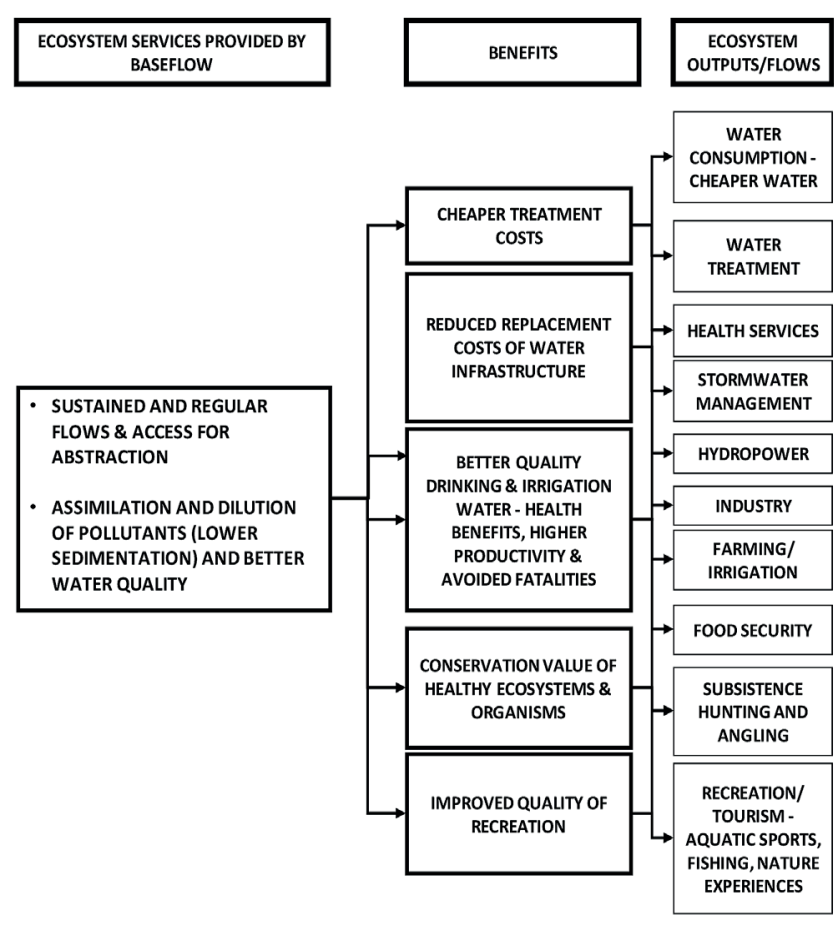

Figure 3

Interrelationships between baseflow, changes in ecosystem services and human benefits

nutrients are moved downslope and deposited in lower-lying areas and water courses, changing the area's geomorphological structure and potentially compromising the quality of the water in the river. Prevention of excessive sediment mobilisation is therefore another key ecosystem service. Generation of higher amounts of sediment than are characteristic of the system results in degradation, and this sediment is likely to be transported towards, and within, water courses, altering natural flow paths and ecosystem processes, and/or be deposited in dams. Man-made dams are designed to contain and consistently supply water to domestic, industrial and agricultural users. Sedimentation may thus reduce their capacity and lifespan (Csiki and Rhoads, 2010) and lead to more frequent spilling and/or the need for costly dredging, and a loss of storage capacity.

\section{Mapping of ecosystem services}

Decision making based on the concept of ecosystem services has gained academic and political traction over recent years, and it is important that these services are able to be mapped and quantified (Daily et al., 2009; Seppelt et al., 2011).

Brauman et al. (2007) identified the potential knowledge gaps of water-related ecosystem services in terms of location, scale and connectivity, and the likelihood that mapping could make a useful contribution to ecosystem service assessments. A common approach to assessing ecosystem services is the use of proxy variables, or surrogates, particularly of land cover, to represent ecosystem processes and to map services using a geographical information system (GIS) (Egoh et al., 2008; Seppelt et al., 2011; Burkhard et al., 2012).

Focusing on water-related ecosystem services in South Africa, Egoh et al. $(2008,2009,2011)$ mapped surface water supply (using runoff) and water flow regulation services (using groundwater) across South Africa. Spatially, results of these studies are presented at the spatial scale of quaternary catchments (i.e. delineated to the fourth level of disaggregation, average area of $\sim 650 \mathrm{~km}^{2}$ ), as well as at the temporal scale of annual averages, which is appropriate for national scale assessments and comparisons, but may not be adequate for municipal/catchment planning.

Although the spatial unit of analysis of many ecosystem service studies may be at a small enough scale to allow for catchment-scale development or rehabilitation planning, temporal scale is generally presented as an annual average, which does not take inter-annual variability, seasonality, nor impacts of individual hydrological events, into account. For catchment and municipal-scale planning, seasonality and inter-annual variability are vital aspects to consider with regard to South Africa's naturally discrete dry and wet seasons, and also the variations in summer rainfall which are associated with the cycle of the El-Niño Southern Oscillation (Malherbe et al., 2016).

Relatively few studies have been reported which use simulation models to map ecosystem services (Seppelt et al., 2011), and many rely on expert opinion to provide links to land cover data. The application of models that operate according to the biophysical principles and feedback mechanisms of the hydrological cycle that represent the water flow through the landscape over long time periods provides an advance in the way that maps of water-related ecosystem services can be derived. The value of daily time-step models in the valuation of water-related ecosystem services, particularly with respect to land use change and feedback mechanisms, has been specifically recognised (Seppelt et al., 2011; Keeler et al., 2012), but has seen little application, particularly in South Africa. In this study, we have used a daily time-step hydrological model which has a hydrological 'memory'. The model carries through water volumes and states by way of a day-to-day water balance, taking feedback mechanisms/complexity into account. It is applied at a small spatial resolution, providing information appropriate to catchment-level decision making and providing a significant advance on previous studies.

\section{Motivation for the study of the uMngeni catchment}

Throughout South Africa, water engineers from large municipalities and water boards face ongoing pressure in terms of water service delivery. Stakeholders such as these are, however, beginning to show a willingness to invest in the rehabilitation of upstream catchments for improved water availability and security downstream (e.g. eThekwini Municipality, 2012). It is, therefore, important for scientists and water resource managers to be able to guide potential investors in terms of where their money may be best spent, i.e., where the largest gains in water could be made through rehabilitation actions. Thus, our aim was to use a spatially explicit method for the prioritisation of areas for investment into EI assets in the uMngeni catchment. This paper describes the motivation for the use of the uMngeni catchment as a case study, as well as the methods used to prioritise areas for investment, and Part 2 describes the results and outputs.

The uMngeni catchment provides an excellent case study for the exploration of the potential value of EI rehabilitation interventions for several reasons. From an institutional perspective, the uMngeni Ecological Infrastructure Partnership (UEIP), which is made up of 23 signatories including both government and non-government agencies and tertiary institutions, all of whom recognise the role that investments in EI can play in the enhancement of water and sanitation services 
in the uMngeni catchment, has made a case for incorporating EI solutions into catchment management (Jewitt et al., 2015a). The South African National Biodiversity Institute (SANBI) has laid considerable groundwork in terms of the role of EI in delivering water-related ecosystem services (e.g. Blignaut et al., 2010; Holness and Skowno, 2013; SANBI, 2014). These studies have found a strong link between healthy EI, delivery of ecosystem services and socio-economic development, and have attracted investment into South Africa to reduce the risks associated with water scarcity and water-related natural disasters such as droughts and floods (SANBI, 2014).

\section{Study area}

The uMngeni catchment $\left( \pm 4400 \mathrm{~km}^{2}, 921 \mathrm{~mm}\right.$ rainfall per annum; Umgeni Water, 2016) is located in the province of KwaZulu-Natal, South Africa, and hosts the country's secondlargest economic hub, and its largest trade port. It is a summer rainfall region mostly characterised by grassland, although much of this area has been cultivated. There are also areas of thicket and bushland, with forest patches (Umgeni Water, 2016). Mean annual temperatures range between 14 and $22^{\circ} \mathrm{C}$. There is a current focus on trade, investment, imports and exports in the following key sectors: manufacturing (automotive, chemical, metals and maritime), agriculture, tourism, transport and logistics, and the green economy (KZN Provincial Planning Commission, 2012). However, economic growth and rapid immigration from rural areas (known as urbanisation; United Nations, Department of Economic and Social Affairs, Population Division, 2014), which exceeds the growth in employment, places increasing pressure on the catchment's natural resources. The emphasis for delivery of water to the catchment's people is currently aimed at more investment into built infrastructure. However, the extent of degradation of EI and loss of natural land cover through transformation within the uMngeni catchment over time has compromised the system's natural ability to perform optimally in delivering strategically important waterrelated ecosystem services (Jewitt et al., 2015a).

The local water authority states that the uMngeni River catchment, supported by a transfer scheme from the adjacent Mooi River catchment, is able to yield approximately $1050 \mathrm{ML}$ per day at a $99 \%$ level of assurance of supply from its various major supply dams, viz., Midmar, Albert Falls, Nagle and Inanda (Umgeni Water, 2015). In the 2013/14 financial year, however, the demand exceeded this amount by over $75 \mathrm{ML}$ per day. Demand is projected to increase to $1800 \mathrm{ML}$ per day by 2043/44 owing to further economic development (Umgeni Water, 2015), which will lead to a lower assurance of supply and a high risk of shortfall. The degradation of natural land (and loss of EI) in the uMngeni catchment over recent decades also implies a change in the partitioning of rainfall, as well as a reduction in the catchment's ability to sustain water-related ecosystem services. This is likely to have led to an increase in surface runoff from areas overgrazed/trampled by livestock, or from hardened roads and roofs, which means that baseflow and groundwater recharge is reduced, and may not be adequate to sustain the catchment in the dry season. In as little as 6 years (2005-2011), the KwaZulu-Natal Province, in which the uMngeni catchment lies, has lost as much as $7.6 \%$ of its natural land due to anthropogenic transformation (mainly due to agriculture, timber plantations, the built environment, dams and mines; Jewitt et al., 2015b), which brings the total of natural land lost in the catchment to almost $48 \%$.

\section{MATERIALS AND METHODS}

This project used established hydrological modelling and GIS techniques to map and model water-related ecosystem service delivery from land cover within the catchment. The following water-related ecosystem services were the focus of the initial mapping process, and they were selected on the basis of previous research elsewhere (e.g. Brauman et al., 2007), discussions with various experts in the field, and available data:

- Water supply: provision of water throughout the year for domestic, industrial, ecological and recreational use (modelled and mapped as streamflow).

- Sustained baseflow: maintenance of water supply during dry periods, and associated water quality maintenance due to assimilation and/or dilution of excess nutrients and waste (see Fig. 3).

- Erosion control and avoidance of excessive sediment losses: avoidance of the mobilisation of excessive sediments from upslope land areas to watercourses and dams, thus affecting the nutrient distribution in the landscape and reducing dam storage capacity, as well as resulting in turbidity in water courses. This includes the transport of soluble nitrates as well as phosphates - the latter, importantly, being sedimentbound (Pettersson et al., 1988).

\section{The ACRU model}

The ACRU (Agricultural Catchments Research Unit) model (Fig. 4), a detailed, daily time-step hydrological model which is able to operate at an appropriate spatial scale for planning, has been widely used for land use impact studies in South Africa, Eritrea, Zimbabwe, United States of America, Germany, New Zealand and Canada.

The model has been used in the Upper Thukela and Baviaanskloof in South Africa for similar ecosystem servicebased studies (Maloti Drakensberg Transfrontier Project, 2007; Blignaut et al., 2010; Mander et al., 2010). Importantly, Warburton et al. (2010) undertook a comprehensive simulation study of the hydrology of the uMngeni catchment with the ACRU model and confirmed the ability of the model to represent the high, low and total flows, with satisfactory comparison statistics (Table 1). They concluded that the model was able provide a satisfactory simulation of streamflow from the range of climates and diversity of land uses present within the catchment.

\section{Flow modelling in ACRU}

Outputs from the ACRU model were used to derive maps of the areas of ecological infrastructure that generate water-related ecosystem services. In the model, processes directly affected by land cover, i.e., canopy interception loss, evaporation from vegetated surfaces and soil water extraction by plant roots all directly contribute to total evaporation (Schulze, 1995). These processes are controlled by a range of parameters including those which control the magnitude of interception and transpiration for different plants in their different stages of growth, rooting pattern and depth and those which affect the composition of the soil and its infiltrability. This affects the amount of water available in each of the soil horizons, which in turn affects the amount of runoff (in the form of quickflow or baseflow) generated. The key output parameters from the model as they relate to the water-related ecosystem services, as already mentioned above, include: 
- Runoff (water supply/streamflow)

- Quickflow (non-delayed stormflow, i.e., water available at or near to the surface on the same day as the rainfall event; water supply)

- Baseflow (water which has infiltrated to lower soil layers and provides recharge to the groundwater store which then discharges into rivers and sustains flows in the dry season)
- Sediment yield (soil mobilised/eroded from the landscape part of the catchment and entering the stream)

Baseflow is modelled explicitly within ACRU, with the value derived from soil water which has percolated out of the base of the sub-soil (B) horizon, and into a baseflow store (Smithers and Schulze, 2004). The store which collects baseflow is connected in the model to the stream channel, and releases water into the

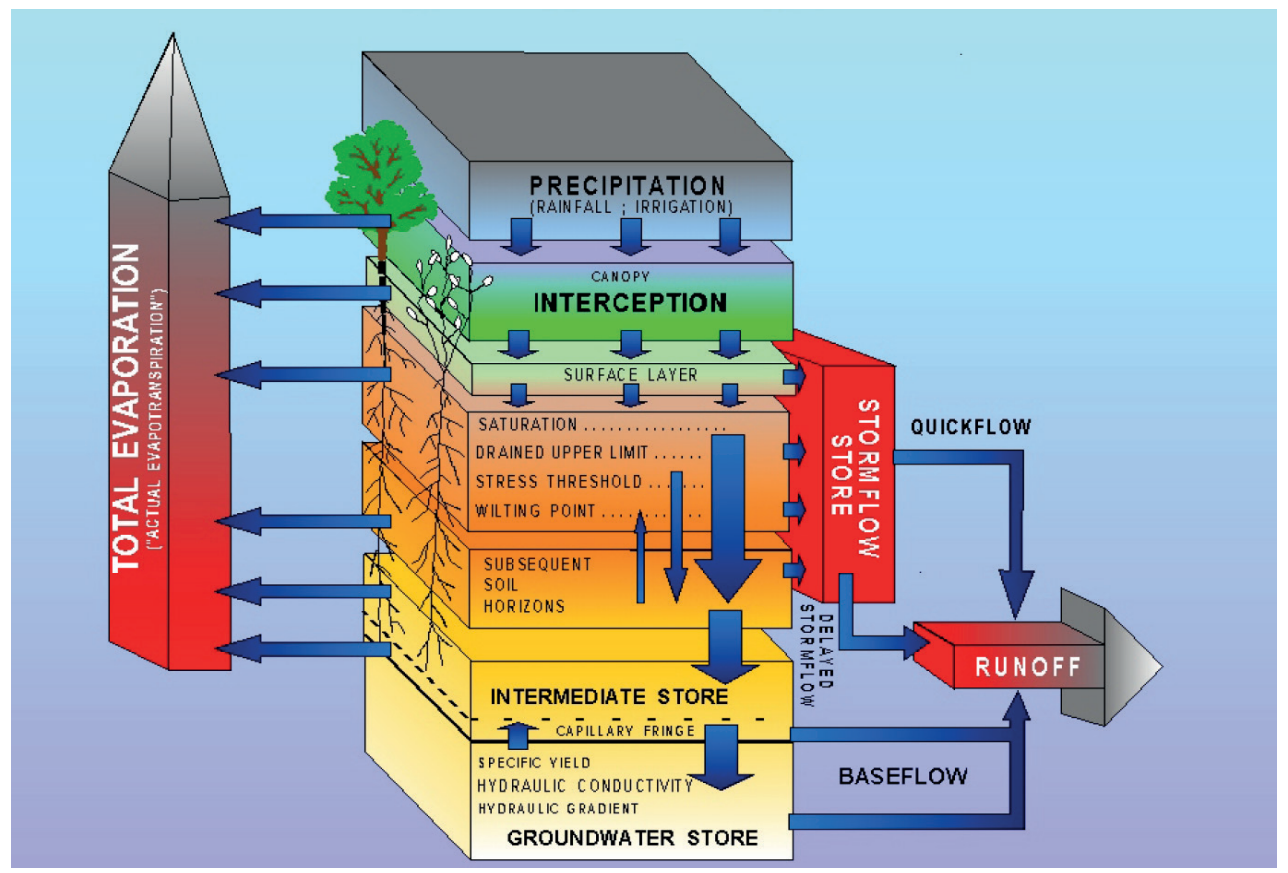

Figure 4

Schematic representation of the ACRU model's water budget (Schulze, 1995)

TABLE 1

Statistics of performance of the ACRU model in various water management units within the uMngeni catchment: Comparison of daily observed and simulated values (from Warburton et al., 2010)

\begin{tabular}{|c|c|c|c|c|}
\hline Water management unit (1987-1998) & Mpendle & $\begin{array}{l}\text { Lions } \\
\text { River }\end{array}$ & Karkloof & Henley \\
\hline Total observed flows (mm) & 3444 & 2507 & 3456 & 2636 \\
\hline Total simulated flows (mm) & 3171 & 2258 & 3006 & 2534 \\
\hline Average error in flow (mm/day) & -0.063 & -0.058 & -0.105 & -0.024 \\
\hline Mean observed flows (mm/day) & 0.796 & 0.582 & 0.803 & 0.629 \\
\hline Mean simulated flows ( $\mathrm{mm} /$ day) & 0.733 & 0.524 & 0.698 & 0.605 \\
\hline \% Difference between means & 7.91 & 9.95 & 13.05 & 3.86 \\
\hline Standard deviation of observed flows (mm) & 1.823 & 1.734 & 1.228 & 1.246 \\
\hline Standard deviation of simulated flows (mm) & 2.011 & 1.947 & 1.305 & 1.541 \\
\hline$\%$ Difference between standard deviations $(\%,<15 \%$ indicating a satisfactory result) & -10.34 & -12.31 & -6.26 & -23.67 \\
\hline Correlation coefficient: Pearson's $R$ (value of 1 indicating a satisfactory result) & 0.915 & 0.939 & 0.844 & 0.886 \\
\hline Regression coefficient (slope, value of $>0$ indicating a satisfactory result) & 1.009 & 1.055 & 0.897 & 1.095 \\
\hline Regression intercept (value of 0 indicating a satisfactory result) & -0.070 & -0.090 & -0.022 & -0.084 \\
\hline Coefficient of determination: $R^{2}$ (value of 0.7 indicating a satisfactory result) & 0.836 & 0.882 & 0.713 & 0.785 \\
\hline Nash-Sutcliffe efficiency index $\left(E_{f}\right)$ (value of 1 indicating a satisfactory result) & 0.802 & 0.847 & 0.655 & 0.654 \\
\hline
\end{tabular}


stream at a rate which depends on the quantity of water in the groundwater store (Smithers and Schulze, 2004). Technically, quickflow in the ACRU model represents the portion of stormflow generated from a rainfall event on a given day that exits the catchment on the same day on which it was generated, plus an amount of quickflow that has been accumulated from preceding days (Smithers and Schulze, 2004).

Sediment yield was calculated within the ACRU model using the Modified Universal Soil Loss Equation (MUSLE; Williams, 1975) and modified Soil Conservation Service (SCS) techniques which are used to calculate stormflow (Smithers and Schulze, 2004). The sediment yield functions used in the ACRU model consider, inter alia, stormflow (as the surrogate for sediment yield transport), peak discharge (used as an indicator of soil particle dislodgement), erodibility characteristics of soils, slope length and a vegetation cover factor that considers both above-ground and surface protection characteristics.

\section{Setting up the sub-catchments and hydrological response units}

Building from Warburton et al. (2010), the catchment has been delineated into 145 sub-catchments (Fig. 5). These sub-catchments range in area from 37 to 11000 ha, and are differentiated on the basis of soils, altitude, topography, land cover, water management practices and gauging stations within the uMngeni catchment. The catchments are in turn grouped into 13 quaternary catchments. For the current study, the 13 quaternaries were further grouped into 6 'dam' catchments to analyse different user groupings based on population clusters and areas supplied by each of the dams and, in turn,

\begin{tabular}{|c|c|c|}
\hline \multicolumn{3}{|c|}{$\begin{array}{l}\text { TABLE } 2 \\
\text { List of dam catchments, quaternary catchments and sub- } \\
\text { catchments }\end{array}$} \\
\hline Dam catchment & $\begin{array}{l}\text { Quaternary } \\
\text { catchments }^{*}\end{array}$ & $\begin{array}{l}\text { Number of sub- } \\
\text { catchments }\end{array}$ \\
\hline \multirow[t]{3}{*}{ Midmar } & Mpendle (U20A) & 7 \\
\hline & Midmar (U20C) & 12 \\
\hline & Lions River (U20B) & 6 \\
\hline \multirow[t]{2}{*}{ Albert Falls } & $\begin{array}{l}\text { Albert Falls } \\
\text { (U20E) }\end{array}$ & 12 \\
\hline & Karkloof (U20D) & 8 \\
\hline \multirow[t]{3}{*}{ Nagle } & $\begin{array}{c}\text { New Hanover } \\
\text { (U20F) }\end{array}$ & 12 \\
\hline & Mqeku (U20K) & 8 \\
\hline & Nagle (U20G) & 15 \\
\hline \multirow{2}{*}{$\begin{array}{l}\text { Henley/ } \\
\text { Pietermaritzburg }\end{array}$} & Henley (U20H) & 9 \\
\hline & $\begin{array}{l}\text { Pietermaritzburg } \\
\text { (U20J) }\end{array}$ & 21 \\
\hline \multirow[t]{2}{*}{ Inanda } & $\begin{array}{l}\text { Table Mountain } \\
\text { (U20J) }\end{array}$ & 11 \\
\hline & Inanda (U20L) & 15 \\
\hline Durban $^{\dagger}$ & Durban (U20M) & 9 \\
\hline
\end{tabular}

approximate corresponding Department of Water and Sanitation catchment in brackets.

Henley/Pietermaritzburg is not a dam catchment per se, but was included owing to the need to incorporate the large city of Pietermaritzburg as a user group. It is recognised that streamflow from the city ultimately feeds the Inanda Dam.

The Durban catchment feeds the uMngeni estuary.

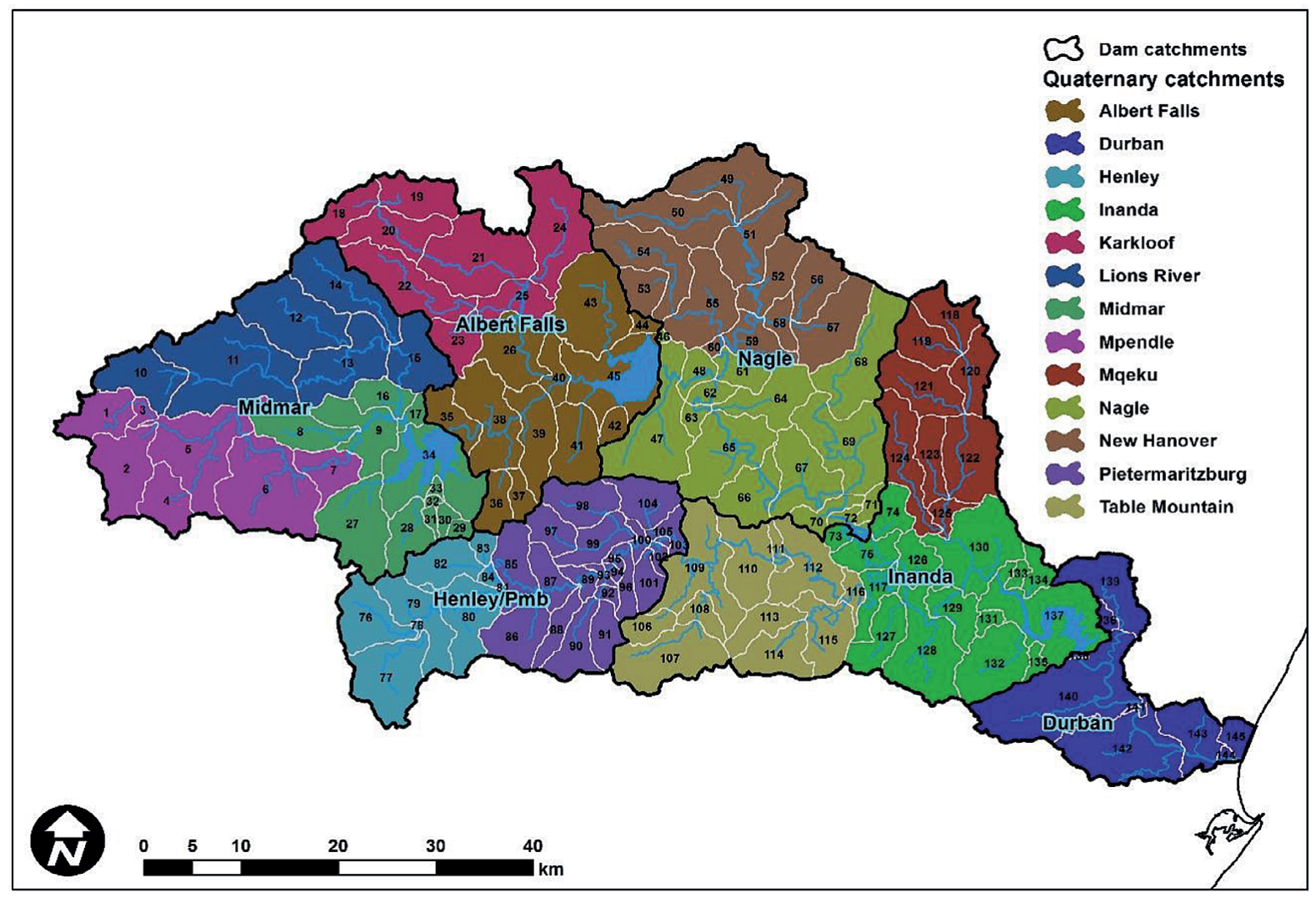

Figure 5

Dam catchments, quaternary catchments and sub-catchments within the uMngeni catchment used for this study 
the demand for ecosystem services from EI within each dam catchment (Table 2). The assessment of ecosystem service requirements and benefits formed part of a separate process of interactions with catchment stakeholders and information gathering on water use, water users and built infrastructure mapping, and is described by Mander et al. (2017). The 145 sub-catchments have each been further sub-delineated into 11 hydrological response units (HRUs), i.e., representative land areas with similar hydrological characteristics/responses, based on vegetation types, specific land uses and classes of urbanisation. Although the sub-catchment boundaries are spatially explicit, the HRUs are not. Within each subcatchment, the non-irrigated land uses are linked to the areas of natural vegetation, which in turn are linked to the areas of commercial agriculture and riparian zones, such that each HRU's individual streamflows are logically routed through each sub-catchment (Fig. 6).

\section{Land cover classes and parameterisation}

Within each of the 145 sub-catchments, each of the 11 land cover types making up the sub-catchment is modelled individually as an HRU. The outputs from the model can therefore quantify and indicate the relative degree of delivery of each service from each land cover type in the various sub-catchments.

The original model configuration (Warburton et al., 2010) was set up using information from the year 2000 National Land Cover imagery (NLC, 2000) and individual sub-catchments, with soils information (Schulze et al., 2008), together with default input values obtained from the ACRU User Manual (Smithers and Schulze, 2004) where no better information was available. This project, however, made use of more recent land cover data available at the time of writing, viz., the 2011 KwaZulu-Natal provincial land cover map (EKZNW and GTI, 2013). Thus, the area of each HRU was updated to reflect this. The land cover classes which were translated into HRUs for the modelling process are summarised for each sub-catchment in Table 3).

Three HRUs were targeted during this study to highlight hydrological differences between degraded and healthy EI, namely the HRUs with invasive alien plants (IAPs), degraded vegetation (which was modelled as overgrazed land using the ACRU model hydrological attributes for overgrazed lands developed by Schulze et al. (2007) for the grasslands of KwaZulu-Natal and the Eastern Cape) for Maloti Drakensberg Transfrontier Project (2007), and untransformed natural vegetation (grassland or forest areas which were not considered by the mapping team to be degraded). Figure 7 shows their distribution and extent, and these HRUs are highlighted in bold in Table 3. Full details of the ACRU parameters used for the modelling process are provided in Table A1, Appendix.

The 2011 land cover data do not contain a mapped coverage of IAPs. A mapped and ground-truthed coverage of invasive alien wattle species (notably Acacia mearnsii and A. dealbata) provided by Umgeni Water (dated 2007) was thus used to represent this HRU. We acknowledge that these data are outdated and limited, and that our estimates indicate that they are far more extensively distributed at the time of the research than in 2007. However, it was the most reliable dataset of IAPs available at the time of the study. Furthermore, wattle trees are acknowledged to be the most problematic alien plant species in South Africa at present (Le Maitre et al., 2013), and give an indication of hydrological responses to woody IAP species.

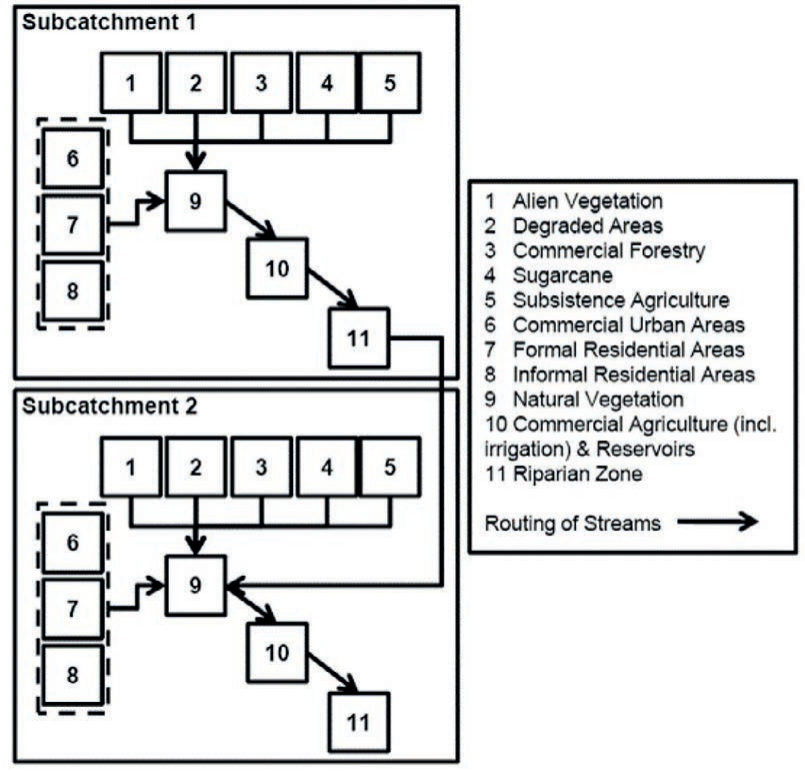

Figure 6

An example of flow paths between each sub-catchment and HRUs within each (Warburton et al. 2010)

Parameters used for the HRUs infested by Acacia mearnsii are shown in Table 4 . The default parameters provided within ACRU were used - however, the key parameter of canopy and interception loss (VEGINT) was increased to a value of 3.3 based on Schulze and Schütte (2014) and Bulcock and Jewitt (2012). This value was determined using fieldwork based on cultivated wattle trees and may thus be higher than might be expected for an IAP infestation. Furthermore, anecdotal evidence suggests that IAPs 'thin out' when they have been established for many years (as opposed to newly established trees), and this may imply a lower water use than for cultivated plantations.

\section{The effects of severe overgrazing}

The hydrological effects of overgrazing, according to Maloti Drakensberg Transfrontier Project (2007), and based on the literature (e.g. Trimble and Mendel, 1995; Sahin and Hall, 1996; Illius and O'Connor, 1999), are summarised below:

- A reduction in above-ground biomass, which in turn results in a decrease in transpiration, with the decrease dependent on whether the original natural veld had a relatively high or low biomass, as well as a decrease in canopy interception and the canopy's protective properties in regard to soil loss.

- A reduction in litter or mulch on the soil surface, which results in increases in the rate of soil water evaporation, thus drying out the topsoil horizon more rapidly and exposing the soil to more severe erosion.

- A possible compaction of the more exposed soil surface through rainfall compaction during convective events and trampling by livestock, which can result in a reduction in the infiltration of rain into the soil.

Table 5 provides an example of how the parameters for degraded vegetation were derived based on the above for the Natal Mist Belt Ngongoni Veld natural vegetation type. ACRU parameters to be changed for the simulation of runoff from degraded areas relative to natural conditions include the 


\begin{tabular}{|c|c|c|c|c|c|c|c|c|}
\hline \multicolumn{9}{|c|}{$\begin{array}{c}\text { TABLE } 3 \\
\text { Accumulated HRU extent for each dam catchment (ha) }\end{array}$} \\
\hline $\begin{array}{l}\text { ACRU HRU (after } \\
\text { Warburton et al. 2010) }\end{array}$ & Midmar & $\begin{array}{l}\text { Albert } \\
\text { Falls }\end{array}$ & $\begin{array}{c}\text { Henley/Pieter- } \\
\text { maritzburg }\end{array}$ & Nagle & Inanda & Durban & $\begin{array}{c}\begin{array}{c}\text { Land cover data (from various } \\
\text { sources) }\end{array} \\
\end{array}$ & Data source \\
\hline $\begin{array}{l}\text { Invasive alien } \\
\text { vegetation (wattle), } \\
\text { Acacia mearnsii }\end{array}$ & 2835 & 846 & 1860 & 153 & 84 & 22 & $\begin{array}{l}\text { Coverage of Acacia mearnsii } \\
\text { infestation }\end{array}$ & $\begin{array}{l}\text { Umgeni Water } \\
\text { Acacia mearnsii/ } \\
\text { dealbata } \\
\text { coverage (2007) }\end{array}$ \\
\hline Built-up & 2445 & 3011 & 17295 & 2690 & 7765 & 14305 & $\begin{array}{l}\text { Mines and Quarries, Built-up/ } \\
\text { Dense Settlement, KZN National } \\
\text { Roads, KZN Main and District } \\
\text { Roads, KZN Railways, Natural } \\
\text { Hard Rock }\end{array}$ & \multirow{5}{*}{$\begin{array}{l}\text { KZN Province } \\
\text { land cover } \\
\text { mapping classes } \\
\text { (EKZNW and } \\
\text { GTI, 2013) } \\
\end{array}$} \\
\hline $\begin{array}{l}\text { Commercial } \\
\text { agriculture/dams }\end{array}$ & 22598 & 12059 & 724 & 3082 & 3998 & 92 & $\begin{array}{l}\text { Orchards (permanent, } \\
\text { irrigated, bananas and citrus), } \\
\text { Cultivation (commercial, annual } \\
\text { crops, dryland), Cultivation } \\
\text { (commercial, annual crops, } \\
\text { irrigated), Water (dams) }\end{array}$ & \\
\hline $\begin{array}{l}\text { Commercial } \\
\text { forestry }\end{array}$ & 15058 & 25063 & 4885 & 25259 & 2270 & 135 & $\begin{array}{l}\text { Plantation and Plantation (clear- } \\
\text { felled). The dominant species } \\
\text { (Eucalyptus grandis, Pinus patula } \\
\text { or Acacia mearnsii) were assigned } \\
\text { using the original ACRU menu } \\
\text { classification }\end{array}$ & \\
\hline $\begin{array}{l}\text { Degraded } \\
\text { vegetation }\end{array}$ & 2955 & 3113 & 1810 & 5444 & 7191 & 368 & $\begin{array}{l}\text { Bare Sand, Degraded Forest, } \\
\text { Degraded Bushland (all types), } \\
\text { Degraded Grassland, Old Fields } \\
\text { (previously grassland), Old } \\
\text { Fields (previously bushland), } \\
\text { Erosion, Airfields }\end{array}$ & \\
\hline Informal residential & 1783 & 1303 & 6613 & 3090 & 9687 & 2241 & Low density settlements & \\
\hline Natural vegetation & 42291 & 24068 & 16552 & 23126 & 51725 & 8617 & $\begin{array}{l}\text { Forest (indigenous), Dense } \\
\text { Thicket and Bush (70-100\% } \\
\text { canopy cover), Medium Bush (< } \\
70 \% \text { canopy cover), Woodland } \\
\text { and Wooded Grassland, Bush } \\
\text { Clumps/Grassland, Grassland, } \\
\text { Forest Glade }\end{array}$ & \\
\hline Pasture grass & 109 & 77 & 357 & 11 & 17 & 412 & Golf courses & \\
\hline $\begin{array}{l}\text { Riparian and } \\
\text { wetlands }\end{array}$ & 2497 & 1176 & 514 & 720 & 362 & 376 & $\begin{array}{l}\text { Natural water, Wetland, Wetland } \\
\text { (mangrove), Water (estuarine) }\end{array}$ & \\
\hline $\begin{array}{l}\text { Subsistence } \\
\text { agriculture }\end{array}$ & 116 & 281 & 3001 & 995 & 7532 & 679 & $\begin{array}{l}\text { Cultivation (subsistence, } \\
\text { dryland), Smallholdings }\end{array}$ & \\
\hline $\begin{array}{l}\text { Sugarcane } \\
\text { (generalised) }\end{array}$ & 0 & 1631 & 242 & 23755 & 9278 & 250 & $\begin{array}{l}\text { Sugarcane (commercial, irrigated } \\
\text { and dryland), Sugarcane (semi- } \\
\text { commercial, emerging farmer, } \\
\text { irrigated and dryland) }\end{array}$ & \\
\hline
\end{tabular}

following monthly parameters, based on Schulze et al. (2007) as developed for Maloti Drakensberg Transfrontier Project (2007) using expert opinion:

- The water use (crop) coefficient (CAY) is reduced by a factor of 1.4 , because overgrazed areas have less above-ground biomass, but with a minimum CAY value of 0.2 in any month.

- The interception loss per rainday (VEGINT), is consequently reduced by $50 \%$.

- The coefficient of initial abstraction (COIAM, an index of infiltrability of rainwater into the soil) is assigned a value of 0.10 for November to March (when thunderstorms occur), 0.15 for April, May and October and 0.20 for June to September, as a result of assumed trampling of grazing areas.

- The percentage litter/mulch (PCSUCO), is reduced to $10 \%$ for all months of the year.

- The root colonisation in the subsoil (COLON), with reduced above-ground biomass, reduces to $60 \%$ in all months (and reduced to $50 \%$ if already lower than 60\%).

- The fraction of surface cover protection is reduced and with the resultant enhanced sediment losses the COVER-factor is increased accordingly to 0.24 in all months and for all Veld Types. 


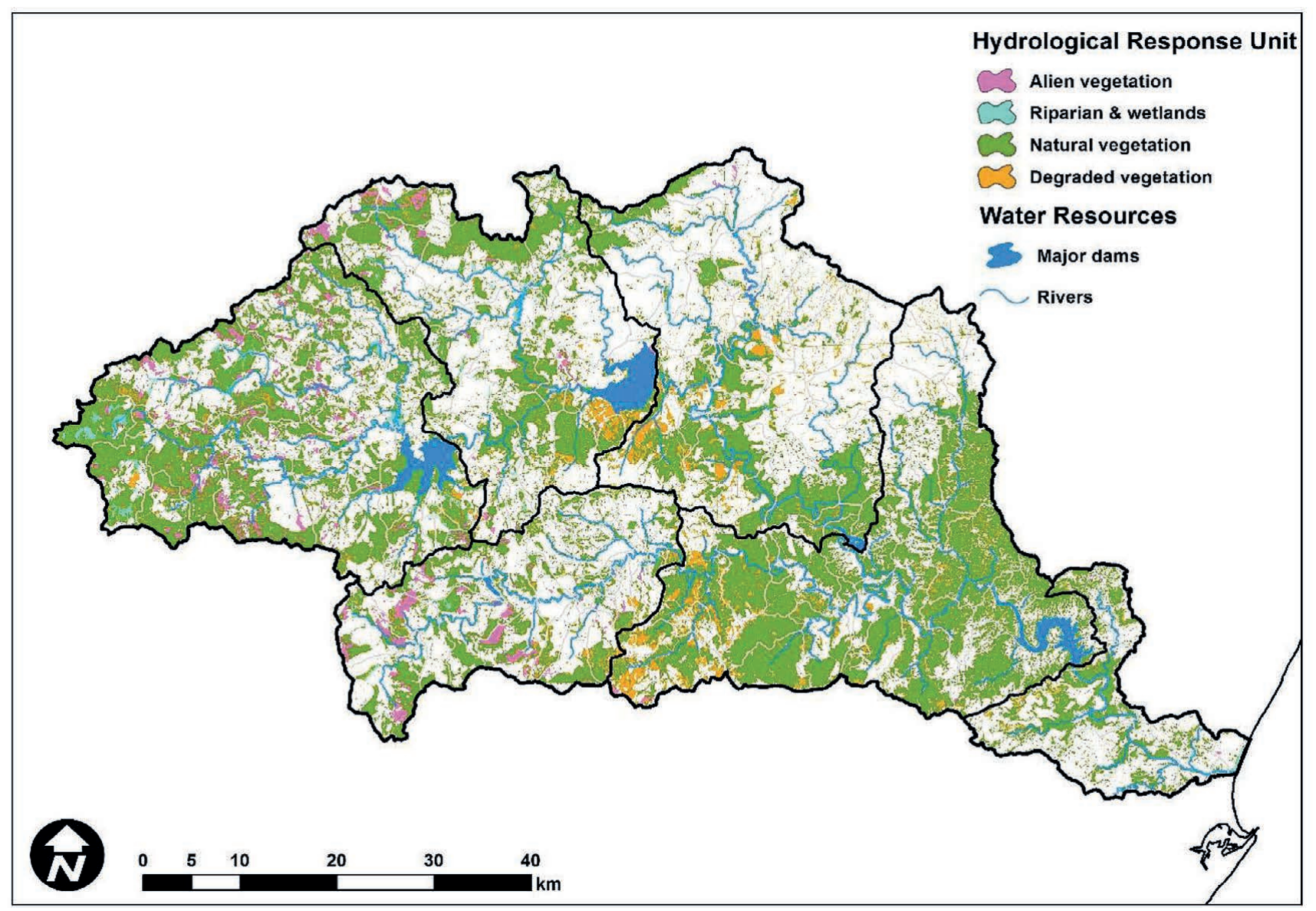

Figure 7

Map of targeted land uses used to model the delivery of water-related ecosystem service outputs in the uMngeni catchment (white areas represent other land uses, e.g. residential, plantations, etc.)

\begin{tabular}{|c|c|c|c|c|c|c|c|c|c|c|c|c|c|}
\hline \multicolumn{14}{|c|}{$\begin{array}{c}\text { TABLE } 4 \\
\text { ACRU parameters used for the modelling of Acacia mearnsii }\end{array}$} \\
\hline HRU & ACRU parameter* & Jan & Feb & Mar & Apr & May & Jun & Jul & Aug & Sep & Oct & Nov & Dec \\
\hline \multirow[t]{7}{*}{ Acacia mearnsii } & CAY & 0.9 & 0.9 & 0.9 & 0.9 & 0.9 & 0.9 & 0.9 & 0.9 & 0.9 & 0.9 & 0.9 & 0.9 \\
\hline & VEGINT & 3.3 & 3.3 & 3.3 & 3.3 & 3.3 & 3.3 & 3.3 & 3.3 & 3.3 & 3.3 & 3.3 & 3.3 \\
\hline & ROOTA & 0.9 & 0.9 & 0.9 & 0.9 & 0.9 & 0.9 & 0.9 & 0.9 & 0.9 & 0.9 & 0.9 & 0.9 \\
\hline & COAIM & 0.35 & 0.35 & 0.35 & 0.35 & 0.35 & 0.35 & 0.35 & 0.35 & 0.35 & 0.35 & 0.35 & 0.35 \\
\hline & PCSUCO & 80 & 80 & 80 & 80 & 80 & 80 & 80 & 80 & 80 & 80 & 80 & 80 \\
\hline & COLON & 60 & 60 & 60 & 60 & 60 & 60 & 60 & 60 & 60 & 60 & 60 & 60 \\
\hline & COVER & 0.08 & 0.08 & 0.08 & 0.08 & 0.08 & 0.08 & 0.08 & 0.08 & 0.08 & 0.08 & 0.08 & 0.08 \\
\hline
\end{tabular}

${ }^{*}$ Monthly values of average crop coefficients (CAY), interception loss (VEGINT, mm.rainday ${ }^{-1}$ ), fraction of roots active in the topsoil (ROOTA), coefficient of initial abstraction (COIAM, which determines infiltrability into the soil and is used to estimate the rainfall abstracted by interception, surface storage and infiltration before stormflow commences), percentage (\%) of surface cover (mulch etc., PCSUCO) - the maximum evaporation from the soil can be suppressed by surface cover such as mulch, litter and surface rock, percentage root colonisation in the subsoil horizon (COLON), and cover factor (C) in MUSLE (COVER)

\section{Climatic data}

The ACRU model was run using daily historical climate data from 1961-1999 (Lynch, 2004), which at the time of the study was the most readily available, consistent and quality controlled dataset. It is recognised that the latest climate data have not been included in the model, but the available record is considered to be sufficiently representative of the catchment's climate, including periods of floods and droughts. Owing to the focus on EI, i.e., terrestrial HRUs such as grasslands, and to allow for more efficient running of the model, each subcatchment was run individually, and results therefore derived and analysed for each. As explained above, the study focused on the quantification and mapping of two water-related ecosystem services, namely, water supply (in the form of baseflow, surface runoff and total streamflow) and sediment yield. 
TABLE 5

ACRU parameters used for the modelling of healthy (pristine) and degraded Ngongoni Veld as an example (Acocks, 1988)

\begin{tabular}{|c|c|c|c|c|c|c|c|c|c|c|c|c|c|}
\hline HRU & $\begin{array}{c}\text { ACRU } \\
\text { parameter* }\end{array}$ & Jan & Feb & Mar & Apr & May & Jun & Jul & Aug & Sep & Oct & Nov & Dec \\
\hline \multirow{7}{*}{$\begin{array}{l}\text { Natal Mist Belt } \\
\text { Ngongoni Veld } \\
\text { (healthy/ pristine) }\end{array}$} & CAY & 0.70 & 0.70 & 0.70 & 0.50 & 0.35 & 0.25 & 0.20 & 0.20 & 0.55 & 0.70 & 0.70 & 0.70 \\
\hline & VEGINT & 1.50 & 1.50 & 1.50 & 1.30 & 1.10 & 1.10 & 1.10 & 1.10 & 1.40 & 1.50 & 1.50 & 1.50 \\
\hline & ROOTA & 0.90 & 0.90 & 0.90 & 0.94 & 0.96 & 1.00 & 1.00 & 1.00 & 0.95 & 0.90 & 0.90 & 0.90 \\
\hline & COAIM & 0.15 & 0.15 & 0.20 & 0.30 & 0.30 & 0.30 & 0.30 & 0.30 & 0.30 & 0.30 & 0.20 & 0.15 \\
\hline & PCSUCO & 73.4 & 73.4 & 73.4 & 73.4 & 73.4 & 73.4 & 73.4 & 73.4 & 73.4 & 73.4 & 73.4 & 73.4 \\
\hline & COLON & 60 & 60 & 60 & 60 & 60 & 60 & 60 & 60 & 60 & 60 & 60 & 60 \\
\hline & COVER & 0.03 & 0.03 & 0.03 & 0.03 & 0.03 & 0.03 & 0.03 & 0.03 & 0.03 & 0.03 & 0.03 & 0.03 \\
\hline \multirow{7}{*}{$\begin{array}{l}\text { Natal Mist Belt } \\
\text { Ngongoni Veld } \\
\text { (degraded) }\end{array}$} & CAY & 0.50 & 0.50 & 0.50 & 0.36 & 0.25 & 0.20 & 0.20 & 0.20 & 0.39 & 0.50 & 0.50 & 0.50 \\
\hline & VEGINT & 0.75 & 0.75 & 0.75 & 0.65 & 0.55 & 0.55 & 0.55 & 0.55 & 0.70 & 0.75 & 0.75 & 0.75 \\
\hline & ROOTA & 0.90 & 0.90 & 0.90 & 0.94 & 0.96 & 1.00 & 1.00 & 1.00 & 0.95 & 0.90 & 0.90 & 0.90 \\
\hline & COAIM & 0.10 & 0.10 & 0.10 & 0.15 & 0.15 & 0.20 & 0.20 & 0.20 & 0.20 & 0.15 & 0.10 & 0.10 \\
\hline & PCSUCO & 10.0 & 10.0 & 10.0 & 10.0 & 10.0 & 10.0 & 10.0 & 10.0 & 10.0 & 10.0 & 10.0 & 10.0 \\
\hline & COLON & 50 & 50 & 50 & 50 & 50 & 50 & 50 & 50 & 50 & 50 & 50 & 50 \\
\hline & COVER & 0.24 & 0.24 & 0.24 & 0.24 & 0.24 & 0.24 & 0.24 & 0.24 & 0.24 & 0.24 & 0.24 & 0.24 \\
\hline
\end{tabular}

${ }^{*}$ Monthly values of average crop coefficients (CAY), interception loss (VEGINT, $m m \cdot$ rainday ${ }^{-1}$ ), fraction of roots active in the topsoil (ROOTA), coefficient of initial abstraction (COIAM, which determines infiltrability into the soil and is used to estimate the rainfall abstracted by interception, surface storage and infiltration before stormflow commences), percentage (\%) of surface cover (mulch etc., PCSUCO) - the maximum evaporation from the soil can be suppressed by surface cover such as mulch, litter and surface rock, percentage root colonisation in the subsoil horizon (COLON), and cover factor (C) in MUSLE (COVER).

\section{CONCLUSION}

There is a growing recognition that investment in ecological infrastructure through rehabilitation and responsible land management can improve delivery of ecosystem services, and thus create a strong platform for socio-economic development. This requires hydrological modelling at spatial and temporal scales which are adequate for planning to allow planners to align potential ecosystem service delivery with stakeholder needs.

The ACRU model was set up to map the delivery of waterrelated ecosystem services associated with three broad land cover types in the uMngeni catchment. We incorporated recent available land cover data into an existing catchment configuration, and set up the model to calculate components of runoff and sediment yield for each HRU in the catchment. The model incorporates hydrological feedback mechanisms, and responds to wet and dry spells in the rainfall record, thus proving extremely useful for identifying inter- and intra-seasonal catchment response characteristics. It should be noted that certain parameters have been updated between this version of the model and the confirmation study (Warburton et al., 2010). However, given the improvement in field-based and information (e.g. Bulcock and Jewitt, 2012) and expert knowledge (Maloti Drakensberg Transfrontier Project, 2007) introduced in this version, we consider these changes to strengthen the model. We acknowledge that there remains a lack of direct field-based measurements for several land use/cover types to inform model parameterisation. However, for a rapid, large-scale, comparative study such as this, we consider the model setup to be sufficiently reliable for water resource planning.

The results of this modelling exercise are presented in Part 2 of this paper ('Mapping of water-related ecosystem services in the uMngeni catchment using a daily time-step hydrological model for prioritisation of ecological infrastructure investment.
Part 2: Outputs'; Hughes et al., 2018), which also discusses the identification of priority areas for each water-related ecosystem service within the catchment, and illustrates the useful contribution that can be made by detailed hydrological modelling towards achieving desirable socio-economic outcomes, such as the provision of a cleaner and more sustained supply of water to South Africa's people.

\section{ACKNOWLEDGEMENTS}

This work was funded and supported by the Development Bank of South Africa's Green Fund and the South African Department of Environmental Affairs. The final report for this project is Jewitt et al. (2015a), and this paper has been drawn predominantly from Chapter 3 of that report. The authors wish to acknowledge the support for the wider project from the Water Research Commission through project K5/2354, the South African National Biodiversity Institute (SANBI), FutureWorks, Umgeni Water, the Institute of Natural Resources, Kevan Zunckel, Prof Mathieu Rouget, Dr Benis Egoh, members of the Centre for Water Resources Research at the University of KwaZulu-Natal and Ezemvelo KZN Wildlife.

\section{REFERENCES}

ACOCKS JPH (1988) Veld Types of Southern Africa. Botanical Survey of South Africa Memoirs 57. Botanical Research Institute, Pretoria, RSA. 146 pp.

BLIGNAUT J, MANDER M, SCHULZE RE, HORAN MJC, DICKENS C, PRINGLE C, MAVUNDLA K, MAHLANGU I, WILSON A, MCKENZIE M and McKEAN S (2010) Restoring and managing natural capital towards fostering economic development: Evidence from the Drakensberg, South Africa. Ecol. Econ. 69 (6) 1313-1323. https://doi.org/10.1016/j.ecolecon.2010.01.007

BRAUMAN KA, DAILY GC, DUARTE TKE and MOONEY HA 
(2007) The nature and value of ecosystem services: an overview highlighting hydrologic services. Annu. Rev. Environ. Resour. 32 67-98. https://doi.org/10.1146/annurev.energy.32.031306.102758

BULCOCK HH and JEWITT GPW (2012) Field data collection and analysis of canopy and litter interception in commercial forest plantations in the KwaZulu-Natal Midlands, South Africa, Hydrol. Earth Syst. Sci. 16 3717-3728. https://doi.org/10.5194/ hess-16-3717-2012.

BURKHARD B, KROLL F, NEDKOV S and MÜLLER F (2012) Mapping ecosystem service supply, demand and budgets. Ecol. Indicators 21 17-29. https://doi.org/10.1016/j.ecolind.2011.06.019

CSIKI S and RHOADS BL (2010) Hydraulic and geomorphological effects of run-of-river dams. Prog. Phys. Geogr. 34 755-780. https:// doi.org/10.1177/0309133310369435

DAILY GC, POLASKY S, GOLDSTEIN J, KAREIVA PM, MOONEY HA, PEJCHAR L, RICKETTS TH, SALZMAN J and SHALLENBERGER R (2009) Ecosystem services in decision making: time to deliver. Front. Ecol. Environ. 7 (1) 21-28. https:// doi.org/10.1890/080025

DLAMINI P, CHIVENGE P, MANSON A and CHAPLOT V (2014) Land degradation impact on soil organic carbon and nitrogen stocks of sub-tropical humid grasslands in South Africa. Geoderma 235 372-381. https://doi.org/10.1016/j.geoderma.2014.07.016

EGOH B, REYERS B, ROUGET M, RICHARDSON DM, LE MAITRE DC and VAN JAARSVELD AS (2008) Mapping ecosystem services for planning and management. Agric. Ecosyst. Environ. 127 (1) 135-140. https://doi.org/10.1016/j.agee.2008.03.013

EGOH B, REYERS B, ROUGET M, BODE M and RICHARDSON DM (2009) Spatial congruence between biodiversity and ecosystem services in South Africa. Biol. Conserv. 142 (3) 553-562. https://doi. org/10.1016/j.biocon.2008.11.009

EGOH BN, REYERS B, ROUGET M and RICHARDSON DM (2011) Identifying priority areas for ecosystem service management in South African grasslands. J. Environ. Manage. 92 (6) 1642-1650. https://doi.org/10.1016/j.jenvman.2011.01.019

ELMQVIST T, SETÄLÄ H, HANDEL SN, VAN DER PLOEG S, ARONSON J, BLIGNAUT JN, GÓMEZ-BAGGETHUN E, NOWAK DJ, KRONENBERG J and DE GROOT R (2015) Benefits of restoring ecosystem services in urban areas. Curr. Opin. Environ. Sustainability 14 101-108. https://doi.org/10.1016/j. cosust.2015.05.001

ETHEKWINI MUNICIPALITY (2012) Spatial Development Framework (SDF) Report 2012/2013, Durban eThekwini Municipality, Durban.

EZEMVELO KZN WILDLIFE and GEOTERRAIMAGE (2013) 2011 KZN Province Land-cover mapping (from SPOT5 satellite imagery circa 2011): data users report and metadata (version 1d). Unpublished report, Biodiversity Research and Assessment, Ezemvelo KZN Wildlife, PO Box 13053, Cascades, 3202.

GUSWA AJ, BRAUMAN KA, BROWN C, HAMEL P, KEELER BL and SAYRE SS (2014) Ecosystem services: Challenges and opportunities for hydrologic modeling to support decision making, Water Resour. Res. 50. https://doi.org/10.1002/2014WR015497

HOLNESS S and SKOWNO A (2013) Mapping EI for the Greater uMngeni Catchment - Technical Metadata. Report compiled for WWF-SA, Hilton, KwaZulu-Natal, South Africa.

HUGHES CJ, DE WINNAAR G, SCHULZE RE, MANDER M and JEWITT GPW (2018) Mapping of water-related ecosystem services in the uMngeni catchment using a daily time-step hydrological model for prioritisation of ecological infrastructure investment. Part 2: Outputs. Water SA 44 (4) 590-600.

ILLIUS AW and O'CONNOR TG (1999) On the relevance of nonequilibrium concepts to arid and semiarid grazing systems. Ecol. Appl. 9 798-813. https://doi. org/10.1890/1051-0761(1999)009[0798:OTRONC]2.0.CO;2

JEWITT G, ZUNCKEL K, DINI J, HUGHES C, DE WINNAAR G, MANDER M, HAY D, PRINGLE C, McCOSH J and BREDIN I (eds.) (2015a) Investing in ecological infrastructure to enhance water security in the uMngeni River catchment. Green Economy Research Report No. 1, Green Fund, Development Bank of Southern Africa, Midrand, South Africa.

JEWITT D, GOODMAN PS, ERASMUS BFN, O'CONNOR TG and WITKOWSKI ETF (2015b) Systematic land-cover change in
KwaZulu-Natal, South Africa: Implications for biodiversity. S. Afr. J. Sci. $111(9 / 10)$

KEELER BL, POLASKY S, BRAUMAN KA, JOHNSON KA, FINLAY JC, O'NEILL A, KOVACS K and DALZELL B (2012) Linking water quality and well-being for improved assessment and valuation of ecosystem services. Proc. Natl Acad. Sci. 109 (45) 18619-18624. https://doi.org/10.1073/pnas.1215991109

KOSGEI JR, JEWITT GPW, KONGO VM and LORENTZ SA (2007) The influence of tillage on field scale water fluxes and maize yields in semi-arid environments: A case study of Potshini catchment, South Africa. Phys. Chem. Earth 32 1117-1126. http://dx.doi. org/10.1016/j.pce.2007.07.027

KZN PROVINCIAL PLANNING COMMISSION (2012) Provincial Growth and Development Plan: February 2012. KZN Province, Pietermaritzburg, South Africa.

LE MAITRE DC, FORSYTH G, DZIKITI S and GUSH M (2013) Estimates of the impacts of invasive alien plants on water flows in South Africa. CSIR. Report Number: CSIR/NRE/ECO/ ER/2013/0067/B. CSIR, Pretoria.

LE MAITRE DC, KOTZEE IM and O'FARRELL PJ (2014) Impacts of land-cover change on the water flow regulation ecosystem service: Invasive alien plants, fire and their policy implications. Land Use Polic. 36 171-181. https://doi.org/10.1016/j.landusepol.2013.07.007

LYNCH SD (2004) The development of a raster database of annual, monthly and daily rainfall for Southern Africa. WRC Report No. 1156/1/04. Water Research Commission, Pretoria.

MALHERBE J, DIEPPOIS B, MALULEKE P, VAN STADEN M and PILLAY DL (2016) South African droughts and decadal variability. Nat. Hazards 80 (1) 657-681. https://doi.org/10.1007/ s11069-015-1989-y

MALOTI DRAKENSBERG TRANSFRONTIER PROJECT (2007) Payment for ecosystem services: developing an ecosystem services trading model for the Mnweni/Cathedral Peak and Eastern Cape Drakensberg Areas. In: Mander M (ed.) INR Report IR281. Development Bank of Southern Africa, Department of Water Affairs and Forestry, Department of Environment Affairs and Tourism, Ezemvelo KZN Wildlife, South Africa.

MANDER M, BLIGNAUT J, VAN NIEKERK M, COWLING R, HORAN M, KNOESEN D, MILLS A, POWELL M and SCHULZE R (2010) Baviaanskloof-Tsitsikamma Payment for Ecosystem services: A feasibility assessment - synthesis report. South Africa National Biodiversity Institute/Working for Water, Pretoria.

MANDER M, JEWITT G, DINI J, GLENDAY J, BLIGNAUT J, HUGHES C, MARAIS C, MAZE K, VAN DER WAAL B and MILLS A (2017) Modelling potential hydrological returns from investing in ecological infrastructure: Case studies from the Baviaanskloof-Tsitsikamma and uMngeni catchments, South Africa. Ecosyst. Services http://dx.doi.org/10.1016/j. ecoser.2017.03.003

NLC (National Land Cover) (2000) Produced by CSIR and ARC Consortium, Pretoria, South Africa.

NATURAL CAPITAL FORUM (2017) What is natural capital? URL: https://naturalcapitalforum.com/about/ (Accessed on 1 June 2018).

PETTERSSON K, BOSTRÖM B and JACOBSEN OS (1988) Phosphorus in sediments - speciation and analysis. In: Persson G and Jansson M (eds) Phosphorus in Freshwater Ecosystems. Developments in Hydrobiology, vol 48. Springer, Dordrecht. 91-101. https://doi. org/10.1007/978-94-009-3109-1_7

RICHARDSON DM, PYŠEK P, REJMÁNEK M, BARBOUR MG, PANETTA DF and WEST CJ (2000) Naturalization and invasion of alien plants - concepts and definitions Diversity Distrib. 6 93-107. https://doi.org/10.1046/j.1472-4642.2000.00083.x

SAHIN V and HALL MJ (1996) The effects of afforestation and deforestation on water yields. J. Hydrol. 178 293-309. https://doi. org/10.1016/0022-1694(95)02825-0

SANBI (2014) A Framework for investing in ecological infrastructure in South Africa. South African National Biodiversity Institute, Pretoria, South Africa.

SCHULZE RE (1995) Hydrology and Agrohydrology. WRC Report No. TT69/95. Water Research Commission, Pretoria. 552 pp. ISBN 1 868451364.

SCHULZE RE, HORAN MJC and FREESE CJ (2007) Hydrological modelling as a tool for ecosystem services trading: case studies 
from the Drakensberg region of South Africa. Unpublished ACRUcons Report No. 56. School of Bioresources Engineering and Environmental Hydrology, University of KwaZulu-Natal, Pietermarizburg, South Africa.

SCHULZE RE and SCHÜTTE S (2014) Complexities of streamflow reductions by commercial plantation forests under varying climatic scenarios. Paper presented at: 17th SANCIAHS National Hydrology Symposium, 1-3 September 2014, University of the Western Cape, Bellville.

SCHULZE RE, MAHARAJ M, WARBURTON ML, GERS CJ, HORAN MJC, KUNZ RP and CLARK DJ (2008) Electronic data accompanying the South African Atlas of Climatology and Agrohydrology. WRC Report No. 1489/1/08. Water Research Commission, Pretoria.

SEPPELT R, DORMANN CF, EPPINK FV, LAUTENBACH $S$ and SCHMIDT S (2011) A quantitative review of ecosystem service studies: approaches, shortcomings and the road ahead. J. Appl. Ecol. 48 630-636. https://doi. org/10.1111/j.1365-2664.2010.01952.x

SMITHERS JC and SCHULZE RE (2004) ACRU Agrohydrological Modelling System User Manual Version 4.00. School of Bioresources Engineering and Environmental Hydrology, University of KwaZulu-Natal, Pietermaritzburg, South Africa.

TRIMBLE SW and MENDEL AC (1995) The cow as a geomorphic agent - a critical review, Geomorphology 13 233-253. https://doi. org/10.1016/0169-555X(95)00028-4
UMGENI WATER (2015) Infrastructure Master Plan 2015: 2015/2016 - 2045/2046, Vol. 1, Planning Services, Engineering and Scientific Services Division, Umgeni Water, Pietermaritzburg.

UMGENI WATER (2016) Infrastructure Master Plan 2015: 2016/20172046/2047, Vol. 1, Planning Services, Engineering and Scientific Services Division, Umgeni Water, Pietermaritzburg.

UNITED NATIONS, DEPARTMENT OF ECONOMIC AND SOCIAL AFFAIRS, POPULATION DIVISION (2014) World Urbanization Prospects: The 2014 Revision. URL: https://esa.un.org/unpd/wup/ Country-Profiles/ (Accessed 10 December 2017).

VAN TOL JJ, LE ROUX PAL, HENSLEY M and LORENTZ SA (2010) Soil as indicator of hillslope hydrological behaviour in the Weatherley Catchment, Eastern Cape, South Africa. Water SA 36 513-520. https://doi.org/10.4314/wsa.v36i5.61985

WARBURTON ML, SCHULZE RE and JEWITT GPW (2010) Confirmation of $A C R U$ model results for applications in land use and climate change studies. Hydrol. Earth Syst. Sci. Discuss. 14 2399-2414. https://doi.org/10.5194/hess-14-2399-2010

WENNINGER J, UHLENBROOK S, LORENTZ S and LEIBUNDGUT C (2008) Identification of runoff generation processes using combined hydrometric, tracer and geophysical methods in a headwater catchment in South Africa/Identification des processus de formation du débit en combinat la méthodes hydrométrique, traceur et géophysiques dans un bassin versant sud-africain. Hydrol. Sci. J. 53 65-80. https://doi.org/10.1623/hysj.53.1.65 


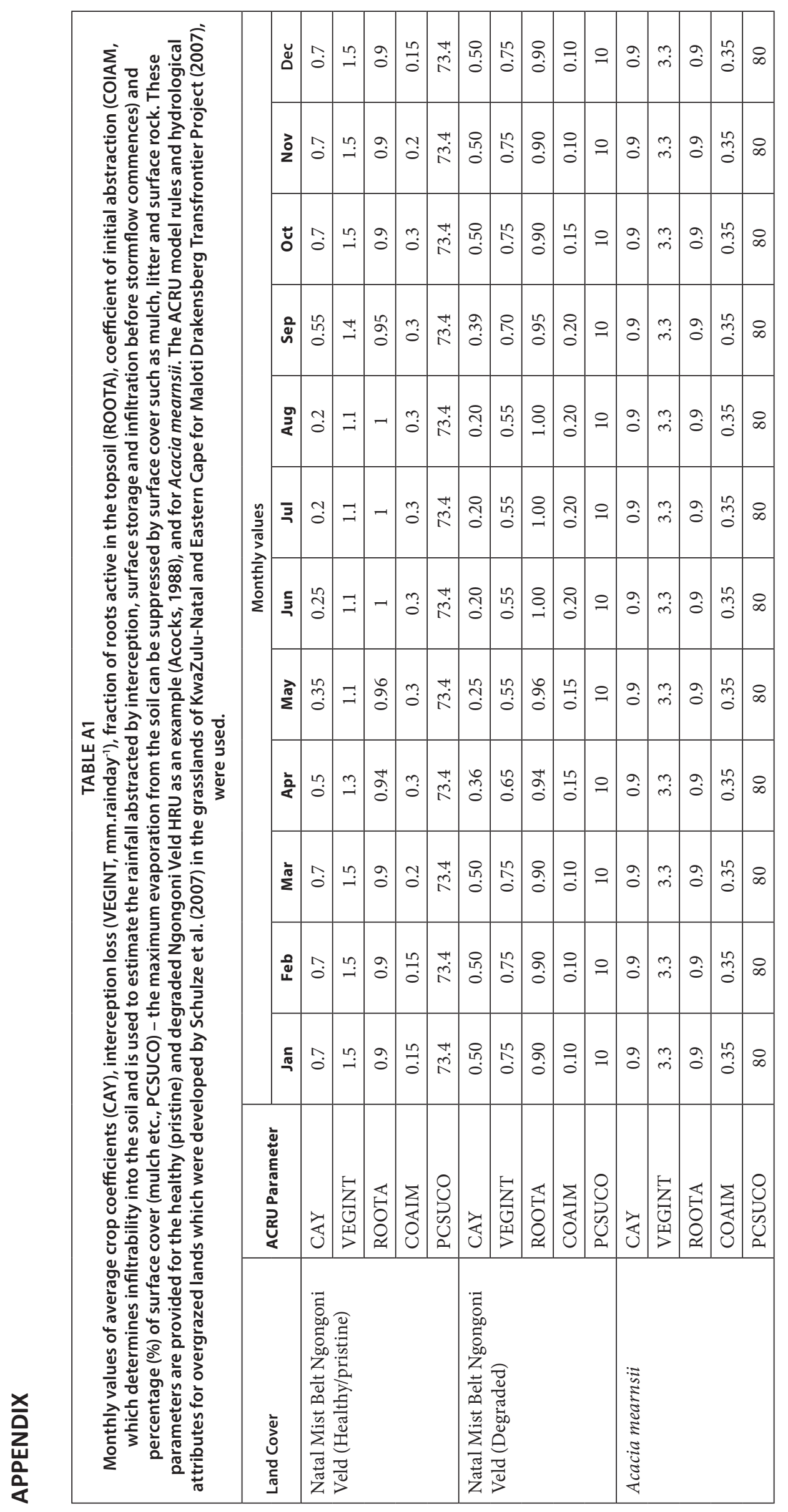

